\title{
Alien flora of Oman: invasion status, taxonomic composition, habitats, origin, and pathways of introduction
}

\author{
Annette Patzelt $(\mathbb{D} \cdot$ Petr Pyšek $(\mathbb{D} \cdot$ Jan Pergl $(\mathbb{D}) \cdot$ Mark van Kleunen $(\mathbb{D}$
}

Received: 16 May 2021/Accepted: 5 December 2021/Published online: 4 January 2022

(C) The Author(s) 2021

\begin{abstract}
We present the first inventory and status assessment of the alien flora of Oman, mainly based on field data collected from 1998 to 2021. The study provides (i) a comprehensive account of alien vascular plant species occurring in the wild in Oman, with information on their taxonomic composition. For each species information is given on (ii) invasion status (casual, naturalized or invasive), biogeography, habitat and life-form characteristics, and pathways of introduction. Further, we (iii) explain the differences in the alien species composition in different parts of
\end{abstract}

Supplementary Information The online version contains supplementary material available at https://doi.org/10.1007/ s10530-021-02711-4.

A. Patzelt $(\square)$

Botany, Ecology, Botanic Gardens, Nature Conservation, 103 Bareeq Al-Shati, PO Box 342, Muscat, Oman

e-mail: annette.patzelt@gmail.com

\section{P. Pyšek $\cdot$ J. Pergl}

Institute of Botany, Department of Invasion Ecology,

Czech Academy of Sciences, 25243 Průhonice, Czech

Republic

P. Pyšek

Department of Ecology, Faculty of Science, Charles

University, Viničná 7, 12844 Prague, Czech Republic

P. Pyšek

Centre for Invasion Biology, Department of Botany \& Zoology, Stellenbosch University, Matieland 7602, South Africa the country, and (iv) analyse the drivers of plant invasions in Oman. Out of the 111 alien species reported (7.7\% of the total Oman vascular flora), 34 species are casuals and 77 naturalized; of the latter seven are considered invasive. The moderate number of alien plant species is likely a result of the country's arid climate, with extremely high summer temperatures and low annual precipitation in most of its area, and the relatively long isolation of the country. The families richest in alien plant species are Fabaceae (17 species), Asteraceae (14 species) and Poaceae (12 species). More alien plants were found in northern Oman (82 species) than in southern Oman (60 species), and very few species are recorded from the central desert ( 7 species). The main habitats colonized

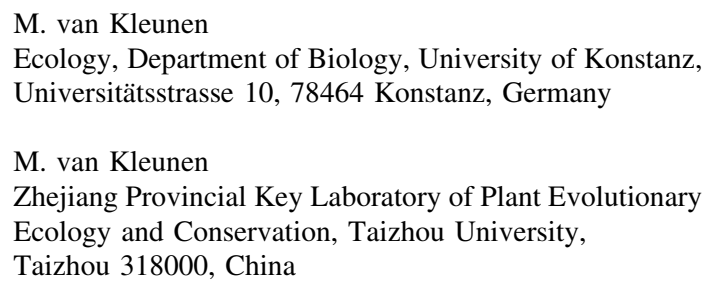


were man-made habitats, either ruderal or agricultural. Most species alien to Oman are native to South America (49 species) or North America (43 species). This inventory provides a knowledge base for developing a national management strategy for alien vascular plants in Oman.

Keywords Exotic species - Non-native species · Tracheophytes · Invasiveness

\section{Introduction}

Environmental changes such as biological invasions are a significant aspect of the Anthropocene (Lewis and Maslin 2015; van Kleunen et al. 2015; Pyšek et al. 2017) and a major threat to biodiversity (Brondizio et al. 2019; Lowe et al. 2004). Humans have introduced thousands of species outside their native ranges (van Kleunen et al. 2018), and although most of those alien species fail to establish persistent populations in the wild, a significant part do, with numbers still increasing (Seebens et al. 2017, 2018). Globally, at least 13,939 plant species $(3.9 \%$ of the extant global vascular flora) have become naturalized in regions outside of their native distribution (van Kleunen et al. 2019) and about $\sim 2500$ species are considered invasive (Pagad et al. 2015). Due to the widely documented impacts of invasive alien species on natural habitats, ecosystems, human health and economy (Pyšek et al. 2012; Kumschick et al. 2015; Nentwig et al. 2018), they have increasingly been acknowledged as a key factor of global environmental transformation (di Castri 1989; Simberloff et al. 2013; Brondizio et al. 2019; Pyšek et al. 2020). In order to manage problematic alien species, it is a prerequisite to have good inventories on their occurrences (Latombe et al. 2017; Pyšek et al. 2018).

In the 2000s, the number of detailed lists of alien plants started to increase rapidly, with e.g. the first specialized national checklists becoming available for Austria (Essl and Rabitsch 2002) and the Czech Republic (Pyšek et al. 2002). Currently, alien species inventories for various taxonomic groups are available for many countries, as well as subnational regions (starting to systematically cover the European continent by DAISIE 2009; see also, e.g., van Kleunen et al. 2015; Dawson et al. 2017; Dyer et al. 2017; Pyšek et al. 2017; Randall 2017; Pagad et al. 2018; Darrigran et al. 2020). These inventories have revealed that alien plant species have virtually invaded all parts of the world but that the numbers vary significantly among regions (van Kleunen et al. 2015; Dawson et al. 2017; Pyšek et al. 2017). A critical milestone was the compilation of the Global Naturalized Alien Flora (GloNAF) database (van Kleunen et al. 2015, 2019), which provided a worldwide overview, but also identified data gaps, particularly in tropical and temperate Asia and in many regions of Africa. Improving knowledge of the distributions of alien plant species in poorly studied regions is important for many reasons, including forming the baseline data for alien species management plans (Latombe et al. 2017) and obtaining a complete picture of global alien species richness (Pyšek et al. 2017).

Over the last four decades, intensive botanical research in Oman has taken place (for references see Patzelt 2014, 2015a), resulting in the description of more than 100 new species with restricted ranges since 1980 and documentation of many new records for the country (Patzelt 2014; Patzelt et al. 2014, 2020). While detailed studies of the vegetation and plant communities are still scarce, an overview of the main vegetation types and land units in Oman shows the varied habitats of the country (Patzelt 2015a). Here, we provide the first comprehensive inventory of alien vascular plant species of Oman and the third such study for the Arabian Peninsula (for Saudi Arabia, see Thomas et al. 2016; for Socotra see Senan et al. 2010). We provide analyses of the invasion status, taxonomic patterns, life forms and habitat characteristics, biogeography, and pathways of introduction to describe spatial and temporal patterns of the alien flora of Oman. This analysis of the patterns and drivers of species invasions in Oman contributes to reducing the existing knowledge gap on plant invasions in subtropical Asia.

\section{Methods}

Study region

The study area covers the Oman territory (Fig. 1). Oman lies between Africa and Asia, in the transition zone between the Holarctic and Palaeotropical kingdoms, as well as between subtropical and tropical 


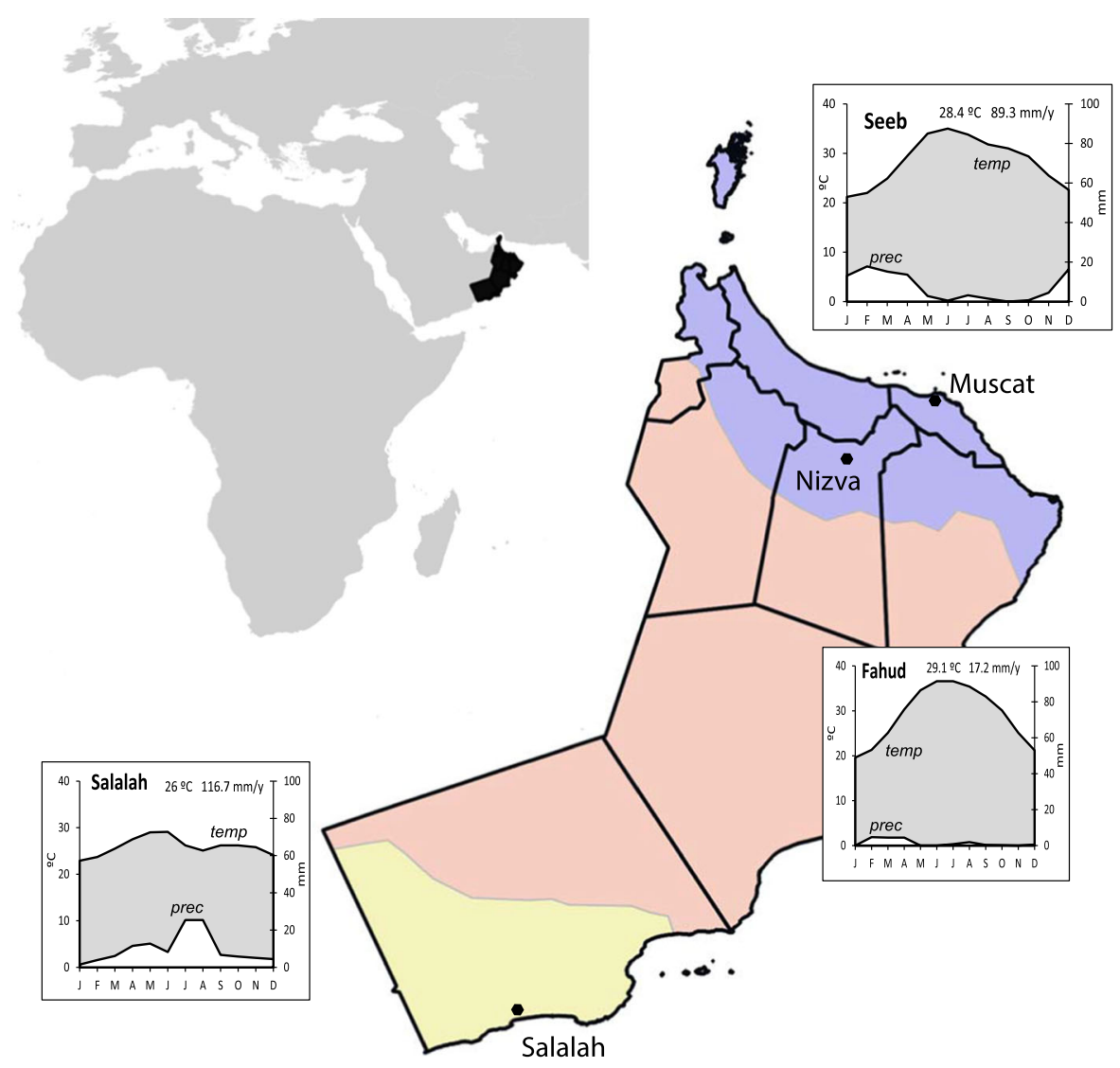

Fig. 1 Map of Oman and its main geographical features, with climagrams for northern Oman (Seeb; blue), central Oman (Fahud; orange) and southern Oman (Salalah; yellow)

climate zones, a position reflected by the presence of species from several biogeographical regions (Miller and Nyberg 1991; Kürschner 1998; Patzelt 2011, 2014, 2015a) (refer to climagrams in Fig. 1). Oman is mainly characterized by arid habitats, with most of the region occupied by sand dunes or rock and gravel desert. However, in stark contrast to the sand and gravel deserts of Oman, the country also contains a semi-deciduous cloud forest ecosystem and evergreen juniper-woodlands supporting high species diversity and many endemic species. Notable species-rich habitats include the mountain areas of southern Oman (reaching up to $2200 \mathrm{~m}$ ), the Hajar mountains of northern Oman (reaching up to c. $3000 \mathrm{~m}$ ), as well as the coastal areas of the central desert, all representing regional centres of plant endemism (Patzelt 2014, 2015a). The southwest monsoon vegetation of southern Oman with tropical deciduous cloud forest and tall-grass savannah is a remnant of a former moist vegetation belt of paleo-
African origin, with many plant species having close links to the flora of East Africa (Kürschner et al. 2004; Patzelt 2011, 2015a).

The capital area (data from Muscat) has an average annual rainfall of $89.3 \mathrm{~mm}$ and the mean annual temperature is $29.1{ }^{\circ} \mathrm{C}$ (Fig. 1). In the central desert, the average annual rainfall is $17.2 \mathrm{~mm}$, and the mean annual temperature is $28.4^{\circ} \mathrm{C}$. In southern Oman (Salalah), the average annual rainfall is $116.7 \mathrm{~mm}$, and the mean annual temperature is $26^{\circ} \mathrm{C}$.

\section{Definitions and delimitations}

We define alien plant species as 'plant taxa in a given area whose presence there is due to intentional or unintentional human involvement, or which have arrived there without the help of people from an area in which they are alien' (Pyšek et al. 2004). We included an alien species if it has been documented to occur in Oman spontaneously in the wild. This 
delimitation excludes plant species that are alien to Oman and are found exclusively in cultivation (for agricultural or horticultural reasons). The invasion status of alien species is described using the categories and definitions by Blackburn et al. (2011): 'Alien species that are sometimes found in the wild but do not form persistent, reproducing populations are classified as casuals (categories CO-C2), and those that form persistent populations are classified as naturalized (categories C3-E).' If a naturalized species is reported to have an environmental and/or socioeconomic impact anywhere in the alien range, it is considered invasive (CBD 2000; IUCN 2000).

\section{Data collection}

The data were collected from 1998 to 2021 by the first author during extensive field work in all regions of the country. The research was further complemented by study of herbarium records as well as by reviewing a large body of literature. The aim was to compile a comprehensive inventory of all alien vascular plant species occurring in Oman. Herbarium vouchers collected by A. Patzelt have been deposited in the following herbaria: E (Royal Botanic Garden Edinburgh), OBG (Oman Botanic Garden Herbarium), ON (National History Museum Oman), SQUH (Sultan Qaboos University Herbarium), K (Royal Botanic Gardens Kew) and M (Botanische Staatssammlung München) (abbreviations following the index herbariorum; http://sweetgum.nybg.org/science/ih).

For each species, information on the habitat type where it occurs was recorded. The habitat classification is based on Patzelt (2015a), but for the present analysis, the habitats were assigned to broad-level types following Hejda et al. (2015) to allow for comparison with other ongoing projects on alien species. The following habitat types were distinguished and used to classify species habitat affinities: 1. Forests, 2. Open forests, 3. Scrub, 4. Grasslands (divided into 4a. natural grasslands, 4b. humanmaintained grasslands. Note: habitat $4 \mathrm{a}$ was not considered in our analysis as it is questionable whether natural grasslands exist in Oman), 5. Sandy, 6. Rocky, 7. Dryland, 8. Saline, 9. Riparian, 10. Wetland, 11. Aquatic, 12. Man-made (divided into 12a. ruderal/ urban habitats, 12b. agricultural habitats).

Based on a literature review and own observations, the plants were assigned to the following life form categories: annual herbs, perennial herbs, annual grass, perennial grass, succulents, climbers, aquatics, bulbous species, shrubs, and trees.

For each of the alien species, we compiled data on its origin, i.e., the geographic region to which it is native, from the GRIN (https://npgsweb.ars-grin.gov) and POWO (http://www.plantsoftheworldonline.org) databases. For species not covered in those database, we did internet searches (as in van Kleunen et al. 2015). Each species was assigned to one or more of the nine major biogeographically defined areas (TDWG continents) of the Taxonomic Databases Working Group (Brummit 2001). In this scheme, Central America is included in South America, and Asia is split in a temperate and tropical part. Moreover, the Pacific Islands are also considered to be one TDWG continent. Species only known from cultivation for which the native ranges are unknown were listed as 'from cultivation only', and taxa for which the geographic region is uncertain are listed as 'obscure origin'. Each species could be classified into several categories within the factors describing habitats, life forms and regions of the native range.

Statistical analysis

We tested (i) whether species habitat affinities differ among casual, naturalized and invasive species. For this, the habitat types were merged into five broad categories representing woody vegetation (habitat types no. 1-3 above), grassland (4), stressed habitats (5-8), water-related habitats (9-11) and man-made habitats (12). Further, we explored whether (ii) the alien species occurring in the north and south of Oman differ according to the pathway of introduction. We describe the patterns of differences in life history and origin among the casual, naturalized and invasive species, but we could not statistically test the patterns due to a high number of zeros in individual categories. All tests were done in R (ver. 3.6.2) by using species counts analyzed by generalized linear models with a log-link function and Poisson distribution with control for overdispersion (if needed using the quasi-Poisson setting). To test in which category the counts were lower or higher than expected by chance, adjusted standardized residuals of G-tests were compared with critical values of a normal distribution (Řehák and Řeháková 1986). All tests and comparisons were made 
on the pool of naturalized species if not mentioned otherwise.

\section{Results}

Alien flora by invasion status

A total of 111 alien vascular plant species are recorded from Oman; a complete list of species with information on their taxonomy, life form, origin, invasion status and habitats is provided in Supplementary Table 1. Thirty-four species are casuals (31\%) and 77 are naturalized (69\%), of which seven are considered invasive. The overall contribution of naturalized alien species to the total flora of the country is $5.3 \%$; casual species represent $2.4 \%$. Table 1 lists the top 10 alien species based on the number of habitats in which they have been recorded.

Taxonomic composition

The 111 alien species represent 38 families. The families richest in species are Fabaceae (17 species), Asteraceae (14 species), Poaceae (12 species), Solanaceae and Amaranthaceae (6 species each), and Convolvulaceae (5 species) (Supplementary Table 1). Eighteen families (49\%) were represented by a single species. Amongst the 77 naturalized plant species, four plant families, Fabaceae (12 species), Asteraceae (9 species), Poaceae ( 7 species) and Solanaceae (6 species) constituted almost half of the species (45\%). The genera richest in alien species are Ipomoea (4 species), Amaranthus, Cenchrus, Euphorbia and Senna (3 species each), while 10 genera are represented by two species and 17 genera by one species (Supplementary Table 1).

\section{Life forms}

The majority of naturalized alien plants in Oman are annual herbs, constituting 32\% (36 species) of all aliens, followed by perennials making up 23\% (25 species) (Fig. 2). Shrubs constituted $10 \%$ of all alien species, climbers $9.1 \%$, trees $6.4 \%$, annual grasses $5.5 \%$, perennial grasses and succulents each $4.6 \%$, and aquatics $2.8 \%$; bulbous plants were neglectable (one species only). The seven invasive species were representatives of four life forms: three annual herbs, one perennial herb, two trees, and one shrub.

\section{Habitats}

The naturalized alien species in Oman are mainly reported from two types of frequently disturbed habitats - 63 species (of which 40 are naturalized, including invasives) occur in agricultural habitat and 53 (44 naturalized) in ruderal habitats. These two habitats harbour $84 \%$ of all recorded naturalized alien species. Eighteen species (14 naturalized) were found in wetlands (including moist and wet areas in wadis with permanent water bodies in part of their course as well as periodically flooded areas in wadis), 16 (15) in anthropogenic grasslands, 15 (14) in open forests, and 12 (12) in scrubland (Fig. 3A). Among habitats harbouring more than 12 aliens, the proportion of invasive species was highest in scrubland, saline and riparian habitats (50\%), followed by open forest $(40 \%)$ (Fig. 3B).
Table 1 The 10 most represented alien plant species in Oman, based on the number of habitats in which they have been recorded

\begin{tabular}{lllll}
\hline Species & Family & Life form & Habitats & Status \\
\hline Prosopis juliflora (Sw.) DC & Fabaceae & Tree & 11 & Invasive \\
Alternanthera pungens Kunth & Amaranthaceae & Annual herb & 7 & Invasive \\
Parthenium hysterophorus L & Asteraceae & Annual herb & 6 & Invasive \\
Leucaena leucocephala (Lam.) de Wit & Fabaceae & Tree & 5 & Invasive \\
Nicandra physalodes (L.) Gaertn & Solanaceae & Annual herb & 5 & Invasive \\
Impatiens balsamina L & Balsaminaceae & Annual herb & 4 & Invasive \\
Lantana camara L & Verbenaceae & Shrub & 4 & Invasive \\
Cucumis sativus L & Cucurbitaceae & Climber & 4 & Naturalized \\
Argemone mexicana L & Papaveraceae & Annual herb & 4 & Naturalized \\
Portulaca oleracea L & Portulacaceae & Annual herb & 4 & Naturalized \\
\hline
\end{tabular}


Fig. 2 Life forms of alien species in Oman

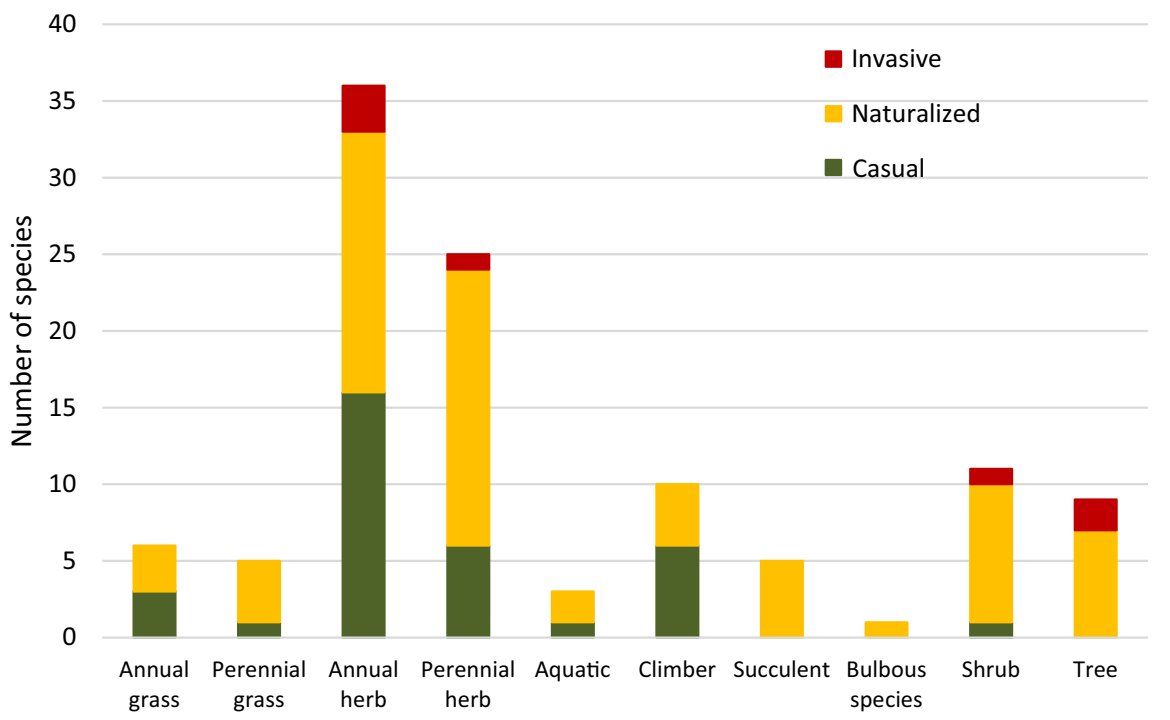

Casual species occurred in seven out of the 13 habitats, naturalized (but not invasive) in nine, and invasive in 11 habitats. The greatest number of casuals (23 species; 68\%) was found in agricultural habitats, followed by ruderal habitats ( 9 species). Casuals were found in only five natural habitats. Forty-two of the 70 naturalized species (excluding the invasive ones) were not found in natural or semi-natural ecosystems at all, i.e., they were only recorded from disturbed and modified ecosystems: agricultural and ruderal (habitats $12 \mathrm{a}$ and $12 \mathrm{~b}$ ). Sixteen naturalized species were predominantly found in modified ecosystems but occurred additionally also in one natural habitat. One species each was found in dryland habitats on sandy or rocky substrate, and two species each were found in saline habitats.

The distribution of alien species in the broad habitat groups significantly differed by status, but only for invasive species $\left(F_{8}=3.58, p<0.001\right)$. There were more invasive species than expected by chance in stressed habitats and fewer in man-made habitats (Fig. 3B). The seven invasive species have the broadest habitat niches, with Prosopis juliflora occurring in 11 of the 13 habitats, Alternanthera pungens in seven habitats, Parthenium hysterophorus in six, and Leucaena leucocephala and Nicandra physalodes in five habitats.

Most alien plant species were recorded from northern Oman (82 species; 74\%), while 60 species
(54\%) were recorded from southern Oman and only six species (6\%) from the central desert (Fig. 4).

Origin

The majority of the alien plants in Oman originate from South America (55 species; 44\%; Supplementary Table 1; Fig. 5), followed by North America (31 species; 28\%), temperate Asia (30 species; 27\%), tropical Asia (28 species; 25\%), and Africa (20 species; $18 \%$ ). A limited number of species originate from Europe (11 species; 10\%) and Australasia (5 species; $5 \%$ ).

Eight species are of obscure origin and three species are known as cultivated forms only. The dominance of the Americas as a source region is even more pronounced for the subset of invasive species, with these two continents accounting for all but one species (i.e., $86 \%$ of the invasive species). The only invasive species not originating from the Americas is Impatiens balsamina, coming from tropical Asia.

Pathways of introduction

Forty-six species (37 naturalized) have been brought to Oman unintentionally (42\%), 43 (22 naturalized) species (39\%) have been imported for agricultural use, and 27 (23 naturalized) species (23\%) are associated with horticulture and used as ornamental plants along roadsides, and in parks and gardens. All species 
Fig. 3 Numbers of naturalized species assigned to individual habitats (A) and to broad habitat categories $(\mathbf{B})$. Arrows indicate whether the observed counts are above or below the counts expected by chance. $*<0.05, * *<0.01$ Stressed habitats refer to dryland, saline and rocky
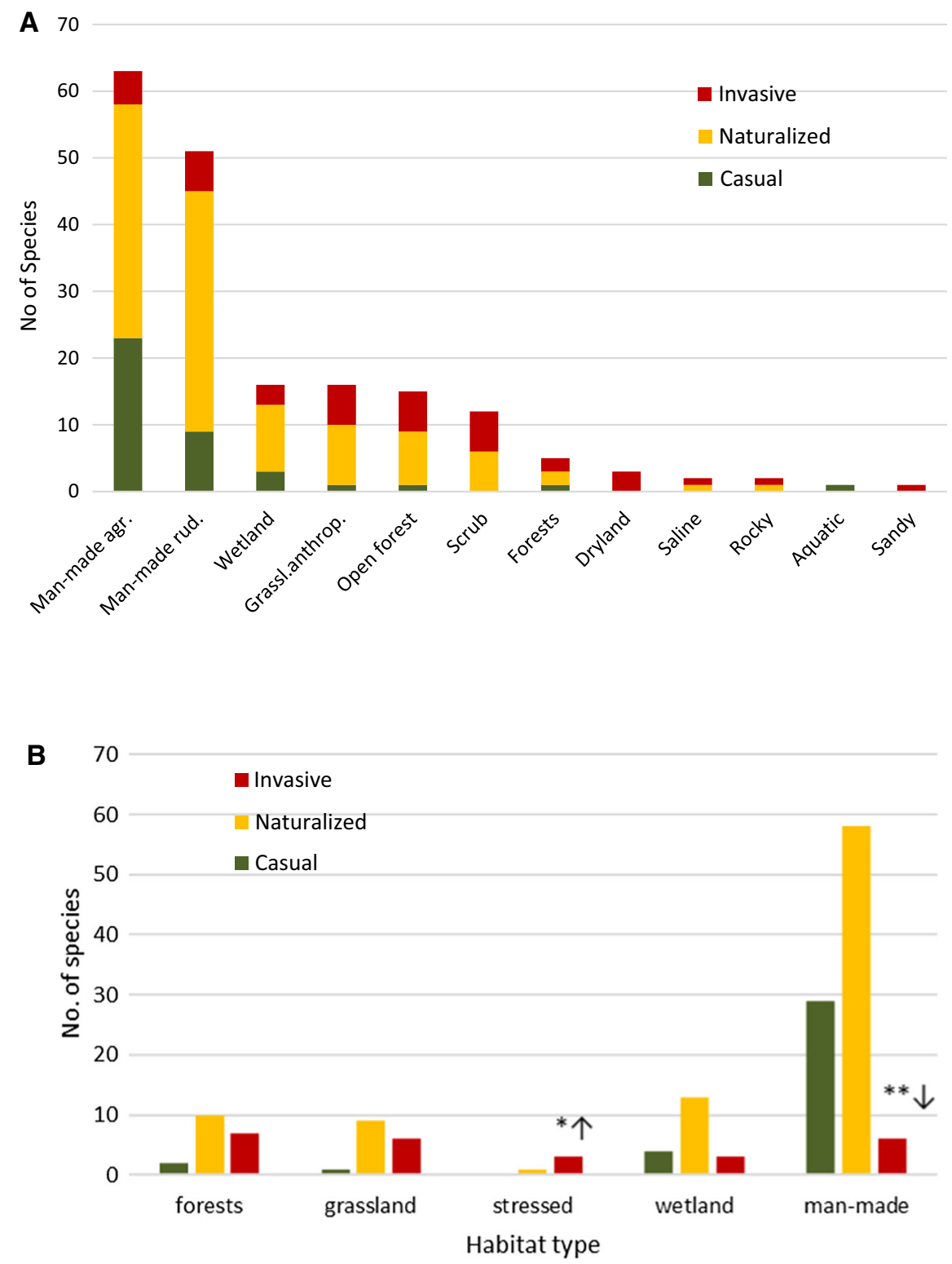

brought in intentionally have escaped from their intended use in agriculture or horticulture. The pathways of introduction to northern and southern Oman significantly differed $\left(F_{2}=3.36, p=0.03\right)$, reflecting that unintentional introductions are underrepresented in northern Oman and over-represented in southern Oman compared to the numbers expected by chance.

As part of this study, Sclerocarya birrea (A. Rich.) Hochst. was newly recorded from several villages in northern Oman, always growing close to irrigation channels. The mature plants may have been planted as seeds, but also young plants were observed in the understory of old trees. As it seems highly likely that the young trees have seeded naturally, we treat the species here as naturalized. 


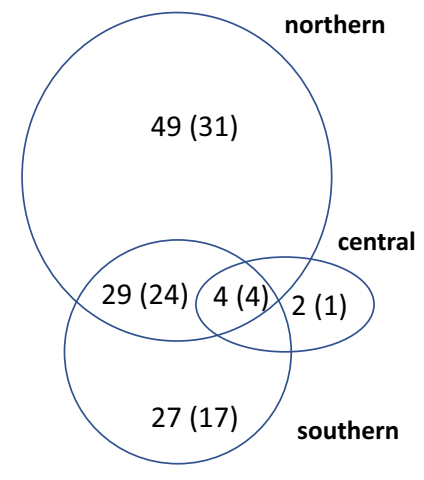

Fig. 4 Size-proportional Venn diagram on the distribution of alien (total number of casual and naturalized; in brackets only naturalized) species in the Oman regions, with the cross-sections indicating the numbers of species shared between regions

\section{Discussion}

Structure and composition of the alien flora: invasion status, taxonomy, and life forms

This inventory of the alien plants of Oman is primarily based on extensive fieldwork from September 1998 up to March 2021, supported by literature analysis. Thus, it reflects the up-to-date state of plant invasions in Oman. We found that the alien flora consists of 111 alien species, which represent $7.7 \%$ of the total flora of the country. The flora of Oman was reported to include 1407 species (Patzelt 2015a). However, is is expected that numbers will be further increasing because of the discoveries of new native species, as well as new records of alien species. Compared to many other regions around the world, the number of alien plant species in Oman is at a low level (Pyšek et al. 2017; Essl et al. 2019). This is to a large degree due to the extremely arid climate lasting for several months a year, but probably also a result of the international isolation of the country until the 1970s.

A comparison with the global naturalized alien flora (Pyšek et al. 2017) and invasive flora (Willis 2017) reveals that the three globally most represented families (Asteraceae, Fabaceae and Poaceae), in terms of species richness, are also richest in alien species in Oman. The predominance of those families among alien species is not surprising given that they are among the largest families globally. However, the Fabaceae and Poaceae have globally still more naturalized species than one would expect based on the total number of species in those families, and many of the most widespread alien species are Asteraceae (Pyšek et al. 2017). Of the 11 most widely distributed naturalized alien species worldwide (Pyšek et al. 2017), three also occur as aliens in Oman, and six others are considered native in Oman. Three out of the global top five of the most widely distributed invasive species (Lantana camara, Pontederia crassipes and Leucaena leucocephala) also occur in Oman as alien species, and two of them are invasive (L. camara and L. leucocephala).

In the alien flora of Oman, annual and perennial herbs largely prevail (56\%), with relatively few shrubs and trees present (17\%). This corresponds well with

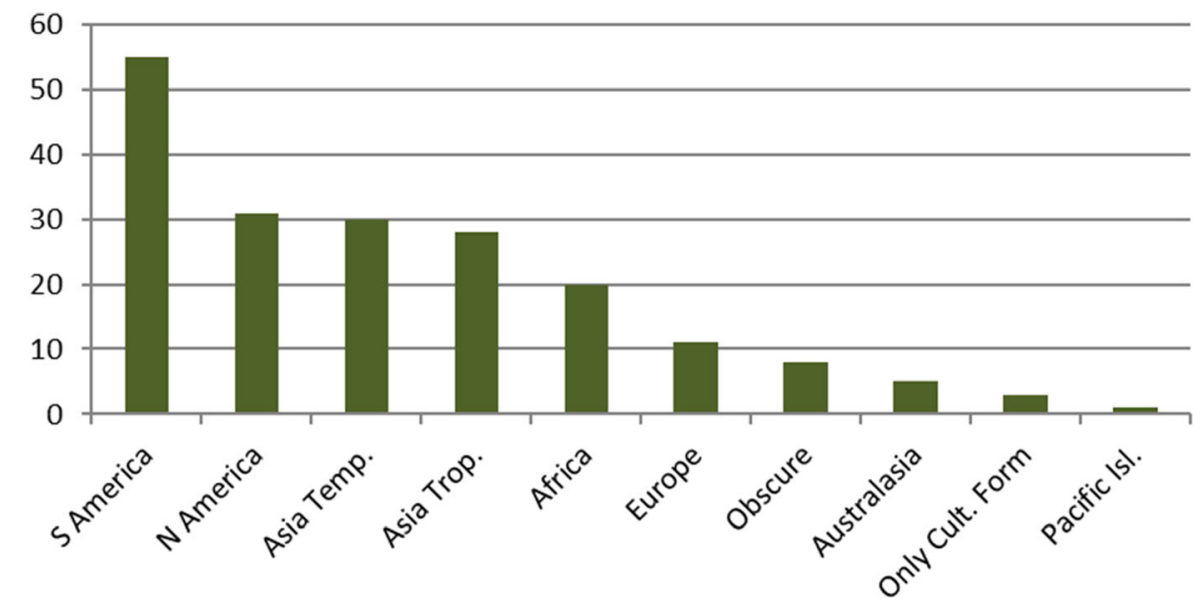

Fig. 5 Origin of the alien flora of Oman shown by region (TDWG continents). The proportional representation of aliens with particular origins within each region exceeds $100 \%$ as some species' native distribution ranges cover more than one region. Species with unclear origin are shown in the category 'obscure' 
the native flora, where annual and perennial herbs constitute $62 \%$ of the species, whereas shrubs and trees constitute $15 \%$. Almost $50 \%$ of the global flora is woody (FitzJohn et al. 2014), and 32\% of all aliens are woody (Pyšek et al. 2017, p. 235-237), but woody species are strongly under-represented as aliens as well as native species in Oman. This pattern is likely due to the harsh arid climatic conditions in most of Oman, which are unfavourable for the establishment and growth of woody species. Herbs have short generation times and are therefore likely to establish and spread rapidly and use the short cool and moist times of the year for reproduction. Especially annual species may complete their short life cycle in just a few weeks and are therefore well adapted to arid climates (Mulroy and Rundel, 1977).

Among the seven invasive species in Oman, four are herbs that form large populations and dominate natural plant communities (Impatiens balsamina, Nicandra physalodes and Parthenium hysterophorus) or displace native species (Alternanthera pungens). The other three invasive species are woody (Lantana camara, Leucaena leucocephala and Prosopis juliflora) and have allelopathic effects on native species. In case of P. juliflora (e.g., Warrag 1994), there are reports of complete dominance of natural habitats in Oman (Patzelt and Lupton 2021).

Temporal patterns and pathways of introduction

In European countries, alien floras can be distinguished into two groups based on their residence time - archaeophytes and neophytes. However, this classification is rarely used in other regions of the world and has not been applied to the present dataset, as no written sources are available regarding Oman's flora before the middle of the nineteenth century. This makes it impossible to infer whether a given species had been introduced before or after 1492 .

The first records of vascular plants of Oman date back to March and April 1838, when Pierre AucherÉloy made a comprehensive collection of plants from northern Oman (then called the Immamat of Muscat). His collection included 218 species, out of which 34 were new to science. The following seven species, listed in our alien vascular plant species inventory, were already noted and collected by Aucher-Éloy: Momordica balsamina, Ocimum sp., Senna sophera, Oxalis corniculata, Ruta chalepensis, Datura metel (today identified as D. innoxia), and Eleusine coracana.

For southern Oman (Dhofar), the first list of species was only published in 1988 (Miller and Morris, 1988), listing 736 species. In their list, 26 alien species were recorded, which are included in the present inventory. We here list 59 alien vascular plant species for southern Oman, 33 species more than in the inventory of 1988. Interestingly, four of the seven invasive species (Prosopis juliflora, Leucaena leucocephala, Parthenium hysterophorus and Lantana camara) were not listed 33 years ago. As it is highly unlikely that they were overlooked by the earlier study, it must be assumed that they were not present then. For some invasive species, the date of the first observation in Oman has been recorded, e.g., Parthenium hysterophorus (Patzelt and Lupton 2021).

Many alien plant species have been imported intentionally into Oman, mostly for ornamental planting and agriculture. As it can be assumed that most if not all species for ornamental horticulture were only introduced to Oman from the late 1970s onwards, the pressure through propagules of these species has dramatically increased in the last four decades. Many horticultural species have been introduced even more recently, and the import of new species for horticulture is still ongoing. It is likely that in the future, further species might escape amenity horticulture and become either casual or naturalized species.

For the plants that escaped from traditional crop cultivation, it can be assumed that most have been brought to the country hundreds if not thousands of years ago, as the oldest oases in northern Oman are up to 5000 years old (Nagieb et al. 2004), and crops have been cultivated since then in irrigated oasis settlements (Gebauer et al. 2007; Hammer et al. 2008; Patzelt 2010). It is hypothesized that agricultural weeds found in the traditional oasis systems constitute species that are likely to have been introduced unintentionally, with their seeds and diaspores contained in the soil of the introduced cultivated crops (e.g., with pomegranate, apricot, and peach from the Eastern Mediterranean region) or as crop contamination. These plants spread with agriculture thousands of years ago and have over the course of time occupied moist ecological niches in Oman, mainly in cultivated fields and ruderal places in oasis settlements.

A number of species introduced as agricultural crops or for amenity horticulture has not yet been 
recorded outside of cultivation (e.g., Acacia farnesiana, Antigonon leptopus, Casuarina equisetifolia, Gomphrena globosa, Momordica charantia, Psidium guajava), although they are considered to have potential to escape from cultivation in the future (i.e., to become alien species).

Climatic and ecological constrains to invasions by alien plants

The trend noted by Pyšek et al. (2017) that the accumulation of alien species is rather fast in colder and Mediterranean regions and slow in arid zonobiomes is supported by the present analysis. The Arabian Peninsula with its arid climate is characterized by low regional invasibility, and Oman has been identified as a coldspot region for alien species richness (Dawson et al. 2017). While it is assumed that climate change will increase the naturalization risk from alien garden plants in Europe (Dullinger et al. 2017; Mayer et al. 2017), the same will not hold true for the Arabian Peninsula. Temperatures in Oman have increased significantly over the past decades; minimum temperatures rose by $3-6{ }^{\circ} \mathrm{C}$ from 1980 to 2008 , while precipitation has decreased (AlSarmi and Washington 2011). The anticipated climate change will thus further reduce the invasibility of Oman and the Arabian Peninsula. Moreover, alien species can make the aridification even worse as alien invasive species have been reported to consume more water than native flora (Le Maitre et al. 2000; Zavaleta 2000).

Many habitats in Oman are characterized by a variety of environmental stress factors such as low nitrogen and phosphorus content, saline or alkaline soils, serpentine soils, low soil moisture, shallow and rocky soils, low precipitation, and high temperatures (Zaffermann et al. 2015). The invasion of habitats under such harsh conditions is likely to be additionally limited by the relatively low arrival rates of propagules compared to ecologically less extreme habitats. Yet, we found that invasive species are over-represented in stressful habitats, compared to naturalized and that are completely missing from such conditions.

Globally, most naturalized plants have been introduced for economic uses (van Kleunen et al., 2020). Similarly, we found that most aliens in Oman were introduced for agricultural or horticultural purposes. However, such species are less likely to be introduced to harsh habitats that are unsuitable for agriculture and gardening. Both propagule limitation and invasion resistance may thus simultaneously contribute to the low numbers of alien plants in many habitats in Oman and the Arabian Peninsula, as it has been shown for other harsh environments (Zaffermann et al. 2015).

Spatial patterns: local variation in the level of invasion

The geographic distribution of alien plant richness in Oman can be explained by several factors. The most important are climate and habitat availability. It is not surprising that the number of alien species is much lower in the central desert, given the extreme arid climate, low soil availability (mostly gravel and rock) and low fertility (Patzelt, 2015a, b). Indeed, precipitation is one of the key climatic factors shaping the richness of alien floras (Lambdon et al. 2008). In contrast, the oasis ecosystems in northern Oman and the monsoon-affected vegetation in southern Oman provide less stressful habitats for plants and have higher alien species richness.

Although southern Oman locally offers favourable climatic conditions for the invasion of alien vascular plant species, fewer were recorded from there than from northern Oman (59 and 79, respectively). This is surprising, as the south is affected by the southwest monsoon and provides relatively moist climatic conditions for 3-6 months per year. The lower number of alien species is probably a result of three factors. Firstly, until recent years, there was limited ornamental horticulture in southern Oman, mainly restricted to the city of Salalah. Secondly, agricultural areas in southern Oman, except for the Salalah city, are also limited, as local people are traditionally herders and therefore, there is no history of maintaining (permanent) agricultural areas. Thirdly, large areas of southern Oman were very thinly populated until two decades ago. Human population density is frequently a key factor positively correlated with naturalized species richness, as it has been shown for Europe (Pyšek et al. 2010b). The increase in human population size in southern Oman in the last two decades may not yet have resulted in increased alien species richness due to invasion time lags (Crooks 2005), resulting in an invasion debt (Essl et al. 2011). It is thus postulated that the number of alien species in southern Oman may increase in the near future. 
The low number of species recorded from the central desert is a result of extreme environmental conditions, but also suggests that this remote region might still be underexplored in terms of its alien flora. It is assumed that at least the following species are present but not yet recorded as alien species: Catharanthus roseus, Albizia lebbeck, Azadirachta indica, Bougainvillea cf. spectabilis, Oxalis corniculata, Cenchrus purpureus and Solanum lycopersicum. In particular the surrounding area of oil-field accommodation should be systematically surveyed, as alien plants are introduced intentionally to these accommodation villages for ornamental and agricultural purposes. The much higher number of alien plants in northern Oman is likely a result of the man-made habitats present, such as oasis settlements, as well as the much higher human population. Human disturbances promote invasions (Davis et al., 2000; Lockwood et al., 2007), and indeed several observational and experimental studies provide evidence for this (Colautti et al. 2006; Kempel et al. 2013).

Human population is directly related to introduction pressure (Pyšek et al. 2010b; Dawson et al. 2017). Disturbance of soil and vegetation is a prerequisite and assisting feature for the establishment of many species, and such disturbance can be expected to increase with human population density (Chytrý et al. 2008a). This may explain why the number of alien species in Oman is highest in ruderal and agricultural ecosystems, as these are the most disturbed and most densely populated habitats, confirming the patterns reported from other parts of the world (e.g., Chytrý 2008b, Pyšek et al. 2010a, 2010c). It has been speculated that disturbances fail to support naturalization if they exceed a certain threshold (Pyšek et al. 2017). Agriculture in the traditional oasis settlements in northern Oman is still mainly for subsistence. No pesticides or herbicides are used for the control of weeds, and crops are still mainly fertilized with animal manure, minerals and ashes (Bürkert and Schlecht 2010; Patzelt 2015b). Thus, the disturbances are at low to intermediate levels that support the invasion of alien species. Several alien plants have in recent years been newly reported from the oasis ecosystems (Patzelt et al. 2014, 2020), showing that invasion of alien species is an ongoing process in Oman.
Origin of the Oman alien flora: different from global patterns

With regards to the biogeographical classification, the native ranges of the naturalized flora of Oman include the tropical and subtropical regions of the world. For most of the species, however, the native ranges reach into temperate regions, and the available distribution data do not allow to classify clearly the (sub-)tropical origin. The description of ranges is relatively rough, referring to the TDWG continents (Brummit 2001). Globally, the continents that contribute most to the naturalized alien flora are temperate Asia (20.3\%), North America (17.1\%) and Europe (15.1\%), followed by Africa (14.3\%) and South America (12.8\%) (Pyšek et al. 2017). This is in sharp contrast to Oman's naturalized flora where the prevailing donor regions are South America (50\%), temperate Asia (27\%), tropical Asia (25\%), and North America (18\%). Particularly, the low number of species from Europe is remarkable given that Europe, together with Asia, were the main economic partners for Oman for centuries. Possibly, there are only a few European species that are adapted to the arid climate of Oman. Similarly, it was recently shown that only few European species have invaded Sudan, most likely due to unsuitability of the climate there (Omer et al. 2021). It is also surprising that there is only a limited number of alien species from Africa (20 species; $18 \%$ ). Perhaps because tropical African species constitute a major part of the native flora of southern Oman (Patzelt 2014; 2015a), the African species that find suitable habitats in Oman are already present. The preponderance of species from the Americas, in particular South America, may indicate that most alien species have only been introduced in recent decades when trade exchange with the Americas became more frequent.

Comparison with other countries in the region

Apart from this publication, only two other compilation of alien species exist for the Arabian Peninsula (Senan et al. 2010; Thomas et al. 2016). The flora of Saudi Arabia $\left(2,400,000 \mathrm{~km}^{2}\right)$ is estimated to have 2100 species (Miller \& Cope, 1996), which is about one-third richer than Oman with its $\sim 1443$ species (A. Patzelt, unpublished data), but the alien plant list for Saudi Arabia includes only 48 species (Thomas 
et al. 2016). From Socotra, 87 alien taxa represent approximately $9 \%$ of the total flora (Senan et al. 2010). Most were introduced in the past 10 to 20 years. Oman with 111 alien species is thus the country with the highest reported alien plant richness in the Arabian Peninsula. This is surprising given that Saudi Arabia is almost seven times larger than Oman and that the numbers of naturalized species are typically closely correlated with those of native species (Pyšek et al. 2017). The relatively low number of alien species reported for Saudi Arabia, therefore, suggests that this country might still be underexplored in terms of its alien flora.

Impact

Due to the extreme aridity of most areas in Oman, the number of species currently considered to be invasive as well as that of species with a risk of becoming invasive in the future is comparatively small. The only plant species with a massive impact on native species is Prosopis juliflora, whereas the other invasive species have only local to moderate impacts (Patzelt and Lupton, 2021). For most invasive species, holistic national management programs could either eradicate the species from Oman or ensure that the species of concern does not spread further. It is highly recommended that for species which still have localized distributions (e.g., Lantana camara, Sesuvium portulacastrum) an immediate eradication program be started.

\section{Conclusions and outlook}

This publication presents the first inventory of alien vascular plants for Oman, using standard criteria. The compilation of such an inventory is essential for research and as baseline data for guiding conservation policies as well as to prevent or mitigate the impacts caused by alien species on biodiversity and human livelihoods. In terms of knowledge of the alien flora of Oman, our study can trigger additional research within the country, as for many naturalized species, in particular those that are invasive, precise information on their distributions and population sizes is still lacking. Gathering further information on absolute numbers and population sizes and, if possible, monitoring the dynamics of alien species over time will form a solid basis for any planning with a temporal perspective.

The data presented here are essential for informing future policies and the development of an alien species management strategy and its implementation. Oman does not yet have an invasive species management plan. It is hoped that this publication enables the decision-makers to take appropriate action to prevent the further spread of alien plant species, set up a monitoring and impact-assessment program and control the invasive species.

\section{Data availability statements}

The data supporting the results reported in the article can be found in Supplementary Table 1.

Acknowledgements PP and JP were supported by EXPRO grant no. 19-28807X (Czech Science Foundation) and long-term research development project RVO 67985939 (Czech Academy of Sciences). MvK was supported by the German Research Foundation DFG (grant no. 264740629). We are thankful to two anonymous reviewers for helpful comments on the manuscript.

Authors' contributions AP was the project leader, compiled all field data and the inventory, and wrote the first version of the article. PP and MvK were involved in conceiving the idea, implementing paper structure and writing the paper. JP conducted the statistical analyses.

Funding Deutsche Forschungsgemeinschaft, Czech Science Foundation

\section{Declarations}

Conflict of interest The authors declare that they have no conflict of interest.

Open Access This article is licensed under a Creative Commons Attribution 4.0 International License, which permits use, sharing, adaptation, distribution and reproduction in any medium or format, as long as you give appropriate credit to the original author(s) and the source, provide a link to the Creative Commons licence, and indicate if changes were made. The images or other third party material in this article are included in the article's Creative Commons licence, unless indicated otherwise in a credit line to the material. If material is not included in the article's Creative Commons licence and your intended use is not permitted by statutory regulation or exceeds the permitted use, you will need to obtain permission directly from the copyright holder. To view a copy of this licence, visit http://creativecommons.org/licenses/by/4.0/. 


\section{References}

AlSarmi S, Washington R (2011) Recent observed climate change over the Arabian Peninsula. J Geophys Res 116(D11):1-15

Blackburn TM, Pyšek P, Bacher S, Carlton JT, Duncan RP, Jarošík V, Wilson JRU, Richardson DM (2011) A proposed unified framework for biological invasions. Trends Ecol Evol 26:333-339. https://doi.org/10.1016/j.tree.2011.03. 023

Brondizio ES, Settele J, Díaz S, Ngo HT (eds) (2019) Global assessment report on biodiversity and ecosystem services of the Intergovernmental Science-Policy Platform on Biodiversity and Ecosystem Services. IPBES Secretariat, Bonn

Brummit RK (2001) World geographical scheme for recording plant distributions, 2nd edn. Hunt Institute for Botanical Documentation, Pittsburgh

Bürkert A, Schlecht E (eds) (2010) Oases of Oman Livelihood systems at the crossroads. Al Roya Publishing, Muscat, Oman

Castri F (1989) Biological invasions: a global perspective, Drake JA et al (eds.), 1-30, Wiley Publishing

CBD (2000) Alien species that threaten ecosystems, habitats or species. NEP/CBD/COP/5/8. Secretariat of the Convention on Biological Diversity, Nairobi

Chytrý M, Jarošík V, Pyšek P, Hájek O, Knollová I, Tichý L, Danihelka J (2008a) Separating habitat invasibility by alien plants from the actual level of invasion. Ecology 89:1541-1553

Chytrý M, Maskell LC, Pino J, Pyšek P, Vilà M, Font X, Smart SM (2008b) Habitat invasions by alien plants: a quantitative comparison among Mediterranean, subcontinental and oceanic regions of Europe. J Appl Ecol 45:448-458. https://doi.org/10.1111/j.1365-2664.2007.01398.x

Colautti RI, Grigorovich IA, MacIsaac HJ (2006) Propagule pressure: a null model for biological invasions. Biol Invasions 8:1023-1037

Crawley MJ (2007) The R book. John Wiley \& Sons Ltd, Chichester

Crooks JA (2005) Lag times and exotic species: the ecology and management of biological invasions in slowmotion. Ecoscience 12:316-329

DAISIE, (ed) (2009) Handbook of alien species in Europe. Springer, Berlin, p 399

Darrigran G, Agudo-Padron I, Baez P, Belz C, Cardoso F, Carranza A, Collado G, Correoso M, Cuezzo MG, Fabres A, Gregoric DEG, Letelier S, Ludwig S, Mansur MC, Pastorino G, Penchaszadeh P, Carolina Peralta C, Rebolledo A, Rumi A, Santos S, Thiengo S, Vidigal T, Damborenea C (2020) Non-native mollusks throughout South America: emergent patterns in an understudied continent. Biol Invasions 22:853-871. https://doi.org/10.1007/ s10530-019-02178-4

Davis MA, Grime JP, Thompson K (2000) Fluctuating resources in plant communities: a general theory of invasibility. J Ecol 88:528-534

Dawson W, Moser D, van Kleunen M, Kreft H, Pergl J, Pyšek P, Weigelt P, Winter M, Lenzner B, Blackburn TM, Dyer EE, Cassey P, Scrivens SL, Economo EP, Guénard B, Capinha
C, Seebens H, García-Díaz P, Nentwig W, García-Berthou E, Casal C, Mandrak NE, Fuller P, Meyer C, Essl F (2017) Global hotspots and correlates of alien species richness across taxonomic groups. Nat Ecol Evol 1:0186. https:// doi.org/10.1038/s41559-017-0186

Dullinger I, Wessely J, Bossdorf O, Dawson W, Essl F, Gattringer A, Klonner G, Kreft H, Kuttner M, Moser D, Pergl J, Pyšek P, Thuiller W, van Kleunen M, Weigelt P, Winter M, Dullinger S (2017) Climate change will increase the naturalization risk from garden plants in Europe. Glob Ecol Biogeogr 26:43-53

Dyer E, Cassey P, Redding DW, Collen B, Franks V, Gaston KJ, Jones KE, Kark S, Orme CDL, Blackburn TM (2017) The global distribution and drivers of alien bird species richness. PLoS Biol 15:e2000942

Essl F, Rabitsch W (eds) (2002) Neobiota in Österreich. Umweltbundesamt $\mathrm{GmbH}$, Wien

Essl F, Dullinger S, Rabitsch W, Hulme PE, Hulber K, Jarošík V, Kleinbauer I, Krausmann F, Kühn I, Nentwig W, Vilà M, Genovesi P, Gherardil F, Desprez Loustau ML, Roques A, Pyšek P (2011) Socioeconomic legacy yields an invasion debt. Proc Natl Acad Sci USA 108:203-207

Essl F, Dawson W, Kreft H, Pergl J, Pyšek P, van Kleunen M, Weigelt P, Manga T, Dullinger S, Lenzner B, Moser D, Maurel N, Seebens H, Stein A, Weber E, Chatelain C, Inderjit GP, Kartesz J, Morozova O, Nishino M, Nowak PM, Pagad S, Shus W, Winter M (2019) Drivers of the relative richness of naturalized and invasive plant species on Earth. AoB Plants 11:plz051. https://doi.org/10.1093/ aobpla/plz051

FitzJohn RG, Pennell MW, Zanne AE, Stevens PF, Tank DC, Cornwell DK (2014) How much of the world is woody? J Ecol 102:1266-1272. https://doi.org/10.1111/1365-2745. 12260

Gebauer J, Lüdeling E, Hammer K, Nagieb M, Bürkert A (2007) Mountain oases in northern Oman: an environment for evolution and in situ conservation of plant genetic resources. Genet Resour Crop Evol 54:465-481

Hammer K, Gebauer J, Al Khanjari S, Bürkert A (2008) Oman at the crossroad of inter-regional exchange of cultivated plants. Genet Resour Crop Evol. https://doi.org/10.1007/ x10722-008-9385-z

Hejda M, Chytrý M, Pergl J, Pyšek P (2015) Native-range habitats of invasive plants: are they similar to invadedrange habitats and do they differ according to the geographical direction of invasion? Divers Distrib 21:312-321

IUCN (2000) Guidelines for the prevention of biodiversity loss caused by alien invasive species. IUCN, Gland

Kempel A, Chrobock T, Fischer M, Rohr RP, van Kleunen M (2013) Determinants of plant establishment success in a multispecies introduction experiment with native and alien species. Proc Natl Acad Sci USA 110:12727-12732

Kürschner H (1998) Biogeography and introduction to vegetation. In: Ghazanfar SA, Fisher M (Eds.) Vegetation of the Arabian Peninsula. Kluwer, Dordrecht, pp 63-98

Kürschner H, Hein P, Kilian N, Hubaishan MA (2004) The Hybantho durae-Anogeissetum dhofaricae ass. Novaphytosociology, structure and ecology of an endemic South Arabian forest community. Phytocoenologia 34:569-612

Kumschick S, Bacher S, Evans T, Marková Z, Pergl J, Pyšek P, Vaes-Petignat $S$, van der Veer $G$, Vilà $M$, Nentwig W 
(2015) Comparing impacts of alien plants and animals using a standard scoring system. J Appl Ecol 52:552-561. https://doi.org/10.1111/1365-2664.12427

Lambdon PW, Pyšek P, Basnou C, Hejda M, Arianoutsou M, Essl F, Jarošík V, Pergl J, Winter M, Anastasiu P, Andriopoulos P, Bazos I, Brundu G, Celesti-Grapow L, Chassot P, Delipetrou P, Josefsson M, Kark S, Klotz S, Kokkoris Y, Kühn I, Marchante H, Perglová I, Pino J, Vilá M, Zikos A, Roy D, Hulme PE, (2008) Alien flora of Europe: species diversity, temporal trends, geographical patterns and research needs. Preslia 80:101-149

Latombe G, Pyšek P, Jeschke JM, Blackburn TM, Bacher S, Capinha C, Costello MJ, Fernández M, Gregory RD, Hobern D, Hui C, Jetz W, Kumschick S, McGrannachan C, Pergl J, Roy HE, Scalera R, Squires ZE, Wilson JRU, Winter M, Genovesi P, McGeoch MA (2017) A vision for global monitoring of biological invasions. Biol Cons 213:295-308. https://doi.org/10.1016/j.biocon.2016.06. 013

Le Maitre DC, Versfeld DB, Chapman RA (2000) The impact of invading alien plants on surface water resources in South Africa: a preliminary assessment. Water SA 26:397-408

Lewis SL, Maslin MA (2015) Defining the Anthropocene. Nature 519:171-180

Lockwood JL, Hoopes MF, Marchetti MP (2007) Invasion ecology. Blackwell, Malden, MA

Lowe S, Browne M, Boudjelas S, De Poorter M (2004) 100 of the world's worst invasive alien species: a selection from the Global Invasive Species Database. The Invasive Species Specialist Group (ISSG), Species Survival Commission (SSC) of the World Conservation Union (IUCN) Updated and reprinted version

Mayer K, Häuser E, Dawson W, Essl F, Kreft H, Pergl J, Pyšek P, Weigelt P, Winter M, Lenzner B, van Kleunen M (2017) Current and future local naturalization potential of ornamental species planted in urban green spaces and private gardens. Biol Invasions 19:3613-3627. https://doi.org/10. 1007/s10530-017-1594-y

Miller AG, Morris M (1988) Plants of Dhofar, the southern region of Oman. Traditional, economic and medicinal Uses. The Office of the Advisor for Conservation of the Environment, Diwan of Royal Court, Muscat, Oman

Miller AG, Cope TA (1996) Flora of the Arabian Peninsula and Socotra, Vol. 1. Edinburg University Press, Edinburgh

Miller AG, Nyberg JA (1991) Patterns of endemism in Arabia. Flora Et Vegetatio Mundi 9:263-279

Mulroy TW, Rundel PW (1977) Annual plants: Adaptations to desert environments. BioScience 27:109-114

Nagieb M, Siebert S, Lüdeling E, Häser J, Bürkert A (2004) Settlement history of a mountain Oasis in Northern OmanEvidence from land-use and archaeological studies. Erde 135:81-106

Nentwig W, Bacher S, Kumschick S, Pyšek P, Vilà M (2018) More than "100 worst" alien species in Europe. Biol Invasions 20:1611-1621. https://doi.org/10.1007/s10530017-1651-6

Omer A, Kordofani M, Gibreel HH, Pyšek P, van Kleunen M (2021) The alien flora of Sudan and South Sudan: taxonomic and biogeographical composition. Biol Invasions 23:2033-2045. https://doi.org/10.1007/s10530-02102495-7
Pagad S, Genovesi P, Carnevali L, Scalera R, Clout M (2015) IUCN SSC invasive species specialist group: invasive alien species information management supporting practitioners, policy makers and decision takers. Manag Biol Invasions 6:127-135. https://doi.org/10.3391/mbi.2015.6.2.03

Pagad S, Genovesi P, Carenevali L, Schigel D, McGeoch M (2018) Introducing the global register of introduced and invasive species. Sci Data 5:170202. https://doi.org/10. 1038/sdata.2017.202

Patzelt A (2010) Plant communities, endemism and conservation: history and heritage. In: Bürkert A, Schlecht E (eds) Oases of Oman-livelihood systems at the crossroads. Al Roya Press \& Publishing House Sultanate of Oman

Patzelt A (2011) The Themeda quadrivalvis tall-grass savannah of Oman at the crossroad between Africa and Asia. Edinb J Bot 68:301-319. https://doi.org/10.1017/S0960428611000217

Patzelt A (2014) Oman Plant Red Data Book. Oman Botanic Garden Publication No. 1. Diwan of Royal Court, Oman Botanic Garden, Sultanate of Oman. 310 p.

Patzelt A (2015a) Synopsis of the flora and vegetation of Oman, with special emphasis on patterns of plant endemism. Jahrbuch 2015 der Braunschweigischen Wissenschaftlichen Gesellschaft, p. 282-317. http://www. digibib.tu-bs.de/?docid $=00060240$

Patzelt A (2015b) Photographic field guide to the plants of the Western Hajar Mountains, Sultanate of Oman - with a complete checklist of vascular plant species. Sultan Qaboos University, Deanship of Research

Patzelt A, Harrison T, Knees SG, Al Harthi L (2014) Studies in the Flora of Arabia, new records from the Sultanate of Oman XXXI. Edinburgh J Bot 71:161-180. https://doi.org/ $10.1017 / \mathrm{S} 0960428614000067$

Patzelt A, Al Hatmi S, Al Hinai A, Al Qassabi Z, Knees SG (2020) Studies in the Flora of Arabia XXXIV: Sixty new records from the Sultanate of Oman. Edinb J Bot 77:413-437 https://doi.org/10.1017/S0960428620000086

Patzelt A, Lupton D (2021) Invasive alien species of Oman. In: Pullaiah $\mathrm{T}$, Ielmini $M$ (eds) Invasive alien species: Observations and issues from around the world. Wiley Publishing

Pyšek P, Sádlo J, Mandák B (2002) Catalogue of alien plants of the Czech Republic. Preslia 74:97-186

Pyšek P, Richardson DM, Rejmánek M, Webster G, Williamson M, Kirschner J (2004) Alien plants in checklists and floras: towards better communication between taxonomists and ecologists. Taxon 53:131-143

Pyšek P, Chytrý M, Jarošík V (2010a) Habitats and land-use as determinants of plant invasions in the temperate zone of Europe. In: Perrings C, Mooney HA, Williamson M (eds) Bioinvasions and globalization: ecology, economics, management and policy. Oxford University Press, Oxford, pp 66-79

Pyšek P, Jarošík V, Hulme PE, Kühn I, Wild J, Arianoutsou M, Bacher S, Chiron F, Didžiulis V, Essl F, Genovesi P, Gherardi F, Hejda M, Kark S, Lambdon PW, DesprezLoustau A-M, Nentwig W, Pergl J, Poboljšaj K, Rabitsch W, Roques A, Roy DB, Shirley S, Solarz W, Vilà M, Winter M (2010b) Disentangling the role of environmental and human pressures on biological invasions across Europe. Proc Natl Acad Sci USA 107:12157-12162. https:// doi.org/10.1073/pnas.1002314107 
Pyšek P, Bacher S, Chytrý M, Jarošík V, Wild J, Celesti-Grapow L, Gassó N, Kenis M, Lambdon PW, Nentwig W, Pergl J, Roques A, Sádlo J, Solarz W, Vilà M, Hulme PE (2010c) Contrasting patterns in the invasions of European terrestrial and freshwater habitats by alien plants, insects and vertebrates. Glob Ecol Biogeogr 19:317-331. https://doi. org/10.1111/j.1466-8238.2009.00514.x

Pyšek P, Jarošík V, Hulme PE, Pergl J, Hejda M, Schaffner U, Vilà M (2012) A global assessment of invasive plant impacts on resident species, communities and ecosystems: the interaction of impact measures, invading species' traits and environment. Glob Change Biol 18:1725-1737. https://doi.org/10.1111/j.1365-2486.2011.02636.x

Pyšek P, Pergl J, Essl F, Lenzner B, Dawson W, Kreft H, Weigelt P, Winter M, Kartesz J, Nishin M, Antonova LA, Barcelona JF, Cabezas FJ, Cárdenas D, Cárdenas-Toro J, Castańo N, Chacón E, Chatelain C, Dullinger S, Ebel AL, Figueiredo E, Fuentes N, Genovesi P, Groom QJ, Henderson L, Inderjit S, Kupriyanov A, Masciadri S, Maurel N, Meerman J, Morozova O, Moser D, Nickrent D, Nowak PM, Pagad S, Patzelt A, Pelser PB, Seebens H, Shu W, Thomas J, Velayos M, Weber E, Wieringa JJ, Baptiste MP, van Kleunen M (2017) Naturalized alien flora of the world: species diversity, taxonomic and phylogenetic patterns, geographic distribution and global hotspots of plant invasion. Preslia 89:203-274. https://doi.org/10.23855/preslia. 2017.203

Pyšek P, Meyerson LA, Simberloff D (2018) Introducing 'Alien Floras and Faunas', a new series in Biological Invasions. Biol Invasions. https://doi.org/10.1007/s10530-017-1648-1

Pyšek P, Hulme PE, Simberloff D, Bacher S, Blackburn TM, Carlton JT, Dawson W, Essl F, Foxcroft LC, Genovesi P, Jeschke JM, Kühn I, Liebhold AM, Mandrak NE, Meyerson LA, Pauchard A, Pergl J, Roy HE, Seebens H, van Kleunen M, Vilà M, Wingfield MJ, Richardson DM (2020) Scientists' warning on invasive alien species. Biol Rev 95:1511-1534. https://doi.org/10.1111/brv.12627

Randall RP (2017) A global compendium of weeds, 3rd edn. Randall Publ, Mount Helena

Řehák J, Řeháková B (1986) Analýza kategorizovaných dat v sociologii. Academia, Prague (in Czech)

Seebens H, Blackburn TM, Dyer EE, Genovesi P, Hulme PE, Jeschke JM, Pagad S, Pyšek P, Winter M, Arianoutsou M, Bacher S, Blasius B, Brundu G, Capinha C, Celesti-Grapow L, Dawson W, Dullinger S, Fuentes N, Jäger H, Kartesz J, Kenis M, Kreft H, Kühn I, Lenzner B, Liebhold A, Mosena A, Moser D, Nishino M, Pearman D, Pergl J, Rabitsch W, Rojas-Sandoval J, Roques A, Rorke S, Rossinelli S, Roy HE, Scalera R, Schindler S, Štajerová K, Tokarska-Guzik B, van Kleunen M, Walker K, Weigelt P, Yamanaka T, Essl F (2017) No saturation in the accumulation of alien species worldwide. Nature Comm 8:14435. https://doi.org/10.1038/ncomms14435

Seebens H, Blackburn TM, Dyer EE, Genovesi P, Hulme PE, Jeschke JM, Pagad S, Pyšek P, Winter M, Arianoutsou M, Bacher S, Brundu G, Capinha C, Celesti-Grapow L, Dawson W, Dullinger S, Fuentes N, Jäger H, Kartesz J, Kenis M, Kühn I, Liebhold A, Mosena A, Nishino M, Pearman D, Pergl J, Rabitsch W, Rojas-Sandoval J, Roques A, Rorke S, Rossinelli S, Roy HE, Scalera R, Schindler S, Štajerová K, Tokarska-Guzik B, van Kleunen M, Walker
K, Yamanaka T, Essl F (2018) Global rise in emerging alien species results from accessibility of new source pools. Proc Natl Acad Sci USA 115:E2264-E2273. https://doi. org/10.1073/pnas.1719429115

Senan AS, Omashekar RK, Attorre EF, Taleb N,Bruno F (2010) Exotic Species of Socotra Island, Yemen: A first contribution. Ann Bot (Roma), https://rosa.uniroma1.it/rosa04/ annali_di_botanica/article/view/9115/9055

Simberloff D, Martin J-L, Genovesi P, Maris V, Wardle DA, Aronson J, Courchamp F, Galil B, García-Berthou E, Pascal M, Pyšek P, Sousa R, Tabacchi E, Vilà M (2013) Impacts of biological invasions: what's what and the way forward. Trends Ecol Evol 28:58-66

Thomas J, El-Sheikh M, Alfarhan AH, Alatar AA, Sivadasan M, Basahi M, Al-Obaid S, Rajakrishnan R (2016) Impact of alien invasive species on habitats and species richness in Saudi Arabia. J Arid Environ 127:53-65. https://doi.org/ 10.1016/j.jaridenv.2015.10.009

van Kleunen M, Dawson W, Essl F, Pergl J, Winter M, Weber E, Kreft H, Weigelt P, Kartesz J, Nishino M, Antonova L, Barcelona JF, Cabezas FJ, Cárdenas D, Cárdenas-Toro J, Castaño N, Chacón E, Chatelain C, Ebel AL, Figueiredo D, Fuentes N, Groom QJ, Henderson L, Inderjit KA, Masciadri S, Meerman J, Morozova O, Moser D, Nickrent D, Patzelt A, Pelser PB, Baptiste MP, Poopath M, Schulze M, Seebens H, Shu W, Thomas J, Velayos M, Wieringa JJ, Pyšek P (2015) Global exchange and accumulation of nonnative plants. Nature 525:100-103. https://doi.org/10. 1038/nature 14910

van Kleunen M, Essl F, Pergl J, Brundu G, Carboni M, Dullinger S, Early R, González-Moreno P, Groom QJ, Hulme PE, Kueffer C, Kühn I, Máguas C, Maurel N, Novoa A, Parepa M, Pyšek P, Seebens H, Tanner R, Touza J, Verbrugge L, Weber E, Dawson W, Kreft H, Weigelt P, Winter M, Klonner G, Talluto MV, Dehnen-Schmutz K (2018) The changing role of ornamental horticulture in alien plant invasions. Biol Rev 93:1421-1437. https://doi.org/10. 1111/brv. 12402

van Kleunen M, Pyšek P, Dawson W, Essl F, Kreft H, Pergl J, Weigelt P, Stein A, Dullinger S, König C, Lenzner B, Maurel N, Moser D, Seebens H, Kartesz J, Nishino M, Aleksanyan A, Ansong M, Antonova LA, Barcelona JF, Breckle SW, Brundu G, Cabezas FJ, Cárdenas D, Cárdenas-Toro J, Castaño N, Chacón E, Chatelain C, Conn B, de Sá DM, Dufour-Dror J-M, Ebel A-L, Figueiredo E, Fragman-Sapir O, Fuentes N, Groom QJ, Henderson L, Inderjit JN, Krestov P, Kupriyanov A, Masciadri S, Meerman J, Morozova O, Nickrent D, Nowak A, Patzelt A, Pelser PB, Shu W-S, Thomas J, Uludag A, Velayos M, Verkhosina A, Villaseñor JL, Weber E, Wieringa J, Yazlık A, Zeddam A, Winter ZE, M, (2019) The Global Naturalized Alien Flora (GloNAF) database. Ecology 100:e02542. https://doi.org/ 10.1002/ecy. 2542

van Kleunen M, Xu X, Yang Q, Maurel N, Zhang Z, Dawson W, Essl F, Kreft H, Pergl J, Pyšek P, Weigelt P, Moser D, Lenzner B, Fristoe TS (2020) Economic use of plants is key to their naturalization success. Nature Comm 11:3201. https://doi.org/10.1038/s41467-020-16982-3

Warrag MOA (1994) Autotoxicity of mesquite (Prosopis juliflora) pericarps on seed germination and seedling growth. J Arid Environ 27:79-84 
Willis KJ (ed.) (2017) State of the World's Plants 2017. Report. Royal Botanic Gardens, Kew

Zafferman E, Stevens JT, Charles GK, Dunbar-Irwin M, Emam T, Fick S, Morales LV, Walf KM, Young DJN, Young TP (2015) Plant communities in harsh sites are less invaded: a summary of observations and proposed explanations. AoB Plants 7:plv056. https://doi.org/10.1093/aobpla/plv056

Zavaleta E (2000) Valuing ecosystem services lost to Tamarix invasion in the United States. In: Mooney HA, Hobbs RJ (eds) Invasive species in a changing world. Island Press, Washington, DC, pp 261-300

Publisher's Note Springer Nature remains neutral with regard to jurisdictional claims in published maps and institutional affiliations. 